\title{
Tuomo Niemelä - the polyporologist - turns sixty
}

\author{
HEIKKI KOTIRANTA and PERTTI RENVALL
}

\begin{abstract}
KOTIRANTA, H. \& RENVALL, P. 2000: Tuomo Niemelä - the polyporologist turns sixty. - Karstenia 40: 7-8. Helsinki. ISSN 0453-3402.

Tuomo Niemelä (born 25.V.1940), one of the leading mycologists in Finland, is internationally best known for his studies on polypore systematics. His good taxonomic eye and excellent illustrations are highly appreciated among the world's aphyllophorologists. In Finland, most biology students know him as a brilliant university teacher with a delicate sense of humour. His research topics include the ecology and systematics of wood-decaying fungi, the vegetation and plant geography of East Africa, and inflorescence structures and morphological adaptation of vascular plants.
\end{abstract}

Key words: mycologist, polypore, teacher, Tuomo Niemelä

Heikki Kotiranta, Finnish Environment Institute, P.O. Box 140, FIN-00251 Helsinki, Finland. E-mail: heikki.kotiranta@vyh.fi

Pertti Renvall, Kuopio Natural History Museum, Myhkyrinkatu 22, FIN-70100, Kuopio, Finland.E-mail: pertti.renvall@kuopio.fi

The present volume of Karstenia is dedicated to Dr. Tuomo Niemelä, our academic mentor and closest colleague, on the occasion of his $60^{\text {th }}$ birthday.

Tuomo Niemelä was born in May 1940 in a small village in Viljakkala, SW Finland. In 1962 he began to study biology at the University of Helsinki. During his student years he worked at the Finnish Forest Research Institute for several spells. There Prof. Viljo Kujala encouraged him to study wood-rotting fungi. Fieldwork, combined with the magic world of old-growth forests, has always been close to Niemelä's heart, and from the very beginning of his career he travelled in different parts of Finland and collected material of polypores in valuable primeval forests.

In 1970-1988 Niemelä acted as an assistant and lecturer at the Department of Botany, University of Helsinki. From 1989 onwards he has been the head curator of the mycological herbarium of the Botanical Museum (H).

The first steps in Niemelä's taxonomic work were influenced and inspired, e.g., by persons such as Stanislaw Domanski, M.A. Donk, John Eriksson and Herman Jahn, all of them leading European aphyllophorologists of the time.

Niemelä's first scientific paper on polypores dealt with the taxonomy of the genus Albatrellus. He soon turned to the poroid species of the Hymenochaetaceae and defended his doctoral thesis on the Phellinus igniarius complex on $21^{\text {st }}$ November, 1975. To date the best-known part of Niemelä's scientific work comprises of the outstanding papers on the systematics of some difficult polypore groups, not least because of the marvellous line drawings and photographs. Even John Eriksson, the master of Indian ink, was impressed by Niemelä's precise and expressive skill. The monographs of the genera Anomoporia and Skeletocutis are examples of classic works on polypore taxonomy that will serve as highly appreciated and widely used manuals for a long time.

The unprejudiced revisions of the genera $I n$ onotus and Phellinus have opened fresh views to the systematics of the Hymenochaetales. The mapping project Polypore survey of Finland, the classical series On Fennoscandian polypores as well as the 12 astonishing editions of the Guide 
to the polypores of Finland are well known among aphyllophorologists all over the world. The newly published CD Guide to the Polypores of Finland (1999) represents the most novel field in Niemelä's output.

Niemelä has made a remarkable contribution to the conservation of old-growth forests in Finland. Through his creative thought, he has been the primus motor in solving a number of problems linked with the biology of boreal wood-inhabiting fungi. He has described many new species and published several key papers on rare and threatened polypores. The present successful use of polypores and other wood-inhabiting fungi as indicators of old-growth forests in Finland is to a large extent based on Niemelä's work. Many indispensable primeval forest areas have been protected by utilizing the knowledge and new ideas he introduced.

Niemelä taught botany and mycology at the University of Helsinki for over 30 years. In addition to foundation courses he has given lectures on special subjects such as on inflorescence morphology of vascular plants, and on East African biogeography.

In 1981 Niemelä arranged a course on the biology of polypores for the first time, and since then this annual course has been very popular among biology students in Finland. Today the course is well known also abroad and so far there have been participants from nearly ten countries. The course is based on Niemelä's extensive educational collection, and the lectures are spiced with excellent slide shows and unforgettable field trips to old-growth forests.
Niemelä has acted as a supervisor for many students not only from Finland but also from China, Estonia and Taiwan. As a patient teacher he has created a new school of aphyllophorologists in Finland. This concerns not only "professional" mycologists, but also several "amateur" mycologists of professional level. The recently completed large-scale inventory of Finnish oldgrowth forests is a testimony of this. He still identifies the most critical material, and when the collections are infected by moulds, a sarcastic remark on collection bag - "dried in plastic bag" - shows his dry sense of humour. Many scientific papers of his will remain as classics in mycological literature. However, perhaps his most valuable influence on Finnish mycology is his "child", the "Niemelä School."

Niemelä's favourite hobbies include art and antiquarian book collecting, and music. During the field courses in the 1970s and 1980s, he was famous for having a huge number of tapes of dancing music. He acted many times like a professional disc jockey throughout the light summer nights until breakfast - and then began to teach. His good physical shape makes such performances even possible today, although he may sometimes show signs of actually growing up.

Acknowledgements: The English language was reviewed by Michael Collinson, M.A.; he is warmly thanked. 